\title{
11. CREATIVE INTERDISCIPLINARY MATH LESSONS BY MEANS OF MUSIC ACTIVITIES
}

\author{
Jana Hudáková 315
}

Eva Králová 316

\begin{abstract}
The goal of the paper is to introduce the project Comenius "EMP-Maths ", entitled 'Providing Mathematics with Music Activities', in which seven European countries took part. The key chapter is devoted to music activities that Slovak team integrated in the school subject of Mathematics. Music activities were selected and designed in accordance with the content of school subject Mathematics. To each particular theme the project solvers designed methodologies and didactic musical games, contests, music and drama exercises. The authoresses illustrate in detail one example of this integration which was presented during the meeting of 7 European countries in Barcelona in January 2015. Their illustration refers to interconnection of cognitive, affective, and psychomotor goals of both school subjects to develop musical and mathematical abilities of 11 - 12 year old elementary school pupils.
\end{abstract}

Key words: Mathematics, music, project, creativity, experiential learning

\section{Introduction}

"Music is hidden and unconscious mathematical problem of the soul" Gottfried W. Leibniz

The project Comenius „EMP-Maths“, (2013-2016) entitled 'Providing mathematics with music activities' was initiated by Swiss music pedagogues and scientists who searched the ways of improving mathematic literacy skills by means of interconnection and integration of music and mathematics. The main objective of the project is to enhance and innovate the teaching of mathematics by using music activities (Prídavková, Šimčíková, 2015). It indirectly follows the project which was already completed and is entitled 'European Music Portfolio a Creative Way into Languages' (EMP-L), (http://maths. emportfolio.eu/). The research and experience of previous project (EMP-L) indicate that language and music are mutually supportive and that they encourage motivation of pupils by fluent development of their foreign language skills and understanding. Listening, perception and imitation creates basic skills in both subjects: English language and Music education. The project objective was to integrate music in foreign language education at elementary schools. Music activities and games for pupils were directed to improve memory for sounds and structure of the new languages. This approach facilitated language acquisition and contributed to decreasing language barriers and social integration. This social aspect can help to increase confidence in the use of foreign languages, self-expression and improvement of intercultural understanding.

\footnotetext{
315 Assistant PhD., "University of Prešov“ in Prešov from Slovak Republic, hudakoj0@unipo.sk

${ }^{316}$ Assistant Ph.D., “Alexander Dubček University“ of Trenčín from Slovak Republic, eva.kralova@tnuni.sk
} 


\section{Integration of Music Activities in Mathematics in the Project „EMP- Maths"}

In this subchapter we explain why we consider the integration of mathematics and music education to be beneficial for pupils. Mathematics, science and technical educational school subjects are given a prominent significance in present-day society. On the other hand, education in humanities is measured and summarized in tables of technical sciences and is subordinated to them. Artistic education, inclusive of music education, is often entitled Multicultural education or Heritage protection, but artistic-aesthetic ideals are presented to young generation below the surface of the commercial mass media and television shows. Real values are presented mostly in secret.

From this aspect of the two "worlds", one that is favoured - technical world, and the other one that fails to be appreciated morally and financially - cultural world, we consider the project „EMP-Maths“, (2013-2016) entitled 'Providing mathematics with music activities' to be beneficial for educating contemporary children and youth. By the integration of mathematics and music there have been identified new challenges for a kind of equality between the two school subjects Mathematics and Music Education. According to Kopčáková (2014, p. 44) "(...) mathematical education is considered to be the basis for an Information Society. Scientific research shows that present-day school practice fights with the lack of interest, motivation and trust in obtaining mathematical skills. To overcome this condition it is necessary to use innovative and creative strategies and materials. Only then learning maths can offer children more discoveries and they become more interested in them." The key idea of the project is to develop and enhance mathematical abilities and skills by means of cross-cutting themes with the help of music education and music activities. Other important project objective is to enhance interdisciplinary competences of teachers by the course Continual Professional Development in their further education (Prídavková, Šimčíková, 2015)

The supporters and followers of developmental philosophies of 1990s - that place an increased emphasis on understanding our own emotions, empathy, feelings and self-motivation - claim that $80 \%$ of our success depends on our emotional intelligence (Kopčáková, 2015). However, exceptionally and profoundly gifted children do not grow into a successful one, if there is no emotion, motivation, and self-motivation. They can be helped with appropriate training which can improve their emotional intelligence. Music is one of possible devices to deepen emotions, it also helps do differentiate between shapes and patterns of emotions. Thus we consider it important to 'interconnect' mathematics and music education to increase motivation and improve the class climate by means of music activities. Coufal (In Beránek, 2014) highlights four mental qualities of a human being that influence the development of mathematics: a) memory, b) fantasy, c) belief in causality, d) ability to create algorithms. In Slovak comprehensive schools there is a possibility to use integrative aspects of music activities and apply them by fully qualified music teachers at various subjects such as Math, Science, Physical Education, Social 
Studies, Foreign Languages and Native Language. The research results of Králová (In Králová \& Kołodziejski, 2015) show that music activities and background music can affect class climate in lower secondary education, especially higher satisfaction, better cohesion, and lower tensions (at the level of significance 0.01); the competitiveness between pupils at the level of significance 0.05 and class atmosphere to more satisfactory relationships, fewer disagreements with classmates.

\section{Singing the Symmetry or Symmetric 'Mirror' Dialogue}

In the following lines we introduce one example of concretisation of providing maths with music activities" with elementary school pupils in the Slovak Republic. We tried to connect cognitive, affective and psychomotor objectives of both subjects in the sense of developing musical and mathematical ability of $11-12$ year old pupils. The music tasks and activities were designed and selected in accordance with the content of mathematics. To individual examples there were designed methodologies, didactic music games, contests, and music and drama exercises. Each of the seven European countries was supposed to design and perform four integrations of mathematics and music education within the project „EMP-Maths“, (2013-2016). In this subchapter we describe one example of this integration that was designated for international textbook and was presented in Spanish Barcelona in January 2015.

Activity: Singing the Symmetry or Symmetric 'Mirror' Dialogue

The core of both school subjects in curriculum:

Mathematics: Symmetry of the surface. Axial symmetry.

Music Education: Symmetry in music. Crab canon. Renaissance.

Preconditions in Maths: Pupils follow the curriculum about central symmetry. They can move the points or figures within the surface. They sharpen their spatial vision. They can determine whether the geometrical figures are symmetric according to the axis, or centre. They can detect the axial symmetry of an object.

Preconditions in Music: Pupils follow the curriculum about a bar (measure), motive, and conscious, vocal conscious rhythmisation.

Teaching aids: Orff instruments - rhythmic sticks, drums, tambourine, etc., orchestral bells, and xylophone. It is possible to use the records of short motives of popular songs or pieces, blackboard and chalk or an interactive board.

Organisation of spatial positioning in pairs - always one pupil of the pair plays the motive and the other one the response to the musical motive, then another pair continues. Or it can be a teacher and a whole class responding by clapping. As soon as anyone makes a mistake, he or she gets off the game.

Target group: $6^{\text {th }}$ and $7^{\text {th }}$ grade of elementary school, twenty $11-12$ year old pupils.

Timing: $10-15$ minutes devote to fulfilling music aims, and 10 minutes to fulfil the aims in math.

Main learning aims of the lesson and its specific aims (fig. 1):

- Deepen the knowledge of pupils about geometrical figures, symmetry and axial symmetry. 
- Develop their conscious rhythmisation and vocal intonation by means of axial symmetry, according to a bar line.

- Learn Renaissance crab canon.

\begin{tabular}{|l|l|}
\hline Cognitive: \\
Mathematics: Provide pupils with the knowledge about axial symmetry and \\
symmetry. \\
Music: Acquire knowledge about Renaissance and the simple steps of composing \\
in that era. Provide a detailed knowledge about what are motives and symmetry in \\
music and about the crab canon. \\
\hline $\begin{array}{l}\text { Specific learning } \\
\text { aims of the } \\
\text { lesson }\end{array}$ & $\begin{array}{l}\text { Affective: } \\
\text { Mathematics: Perceive geometrical figures in the flat surface and move/transfer } \\
\text { them within axial symmetry. } \\
\text { Music: Perceive musical notes / tones in music space. Develop the ability to } \\
\text { identify the pitch of the tones, become aware of it and use it within the given task. }\end{array}$ \\
\hline $\begin{array}{l}\text { Psychomotor: } \\
\text { Mathematics: Create any figure in the surface according to axial symmetry of } \\
\text { surface. Develop skills in exact drawing and develop fine motor skills. } \\
\text { Music: Create (play, sing or clap) a motive. Create musical response to the motive } \\
\text { by using the technique of crab canon. Develop vocal-intonation skills with the } \\
\text { emphasis on the precise and clear intonation. Acquire the knowledge of the tonal } \\
\text { pitch. Develop the ability to play particular tonal pitch by using the crab canon } \\
\text { technique- development of music-related memory. }\end{array}$ \\
\hline
\end{tabular}

Figure 1. Specific learning aims in the integration of music activities in mathematics

\section{Educational approach used during the lesson:}

- Motivation: discussing mirror image, facial symmetry, symmetry in the nature (flowers, snowflakes, leaves).

- Maths: discussing the symmetry in mathematics - parallels in the axial symmetry (drawing a face of a man, or letters $\mathrm{V}$ or $\mathrm{Y}$ in axial symmetry; the axis will be in the middle of the letter).

- Music: musical dialogue: question and answer - or backward answer (crab canon). Example: when a pupil wishes to speak back, he or she says everything backwards. In music, it would look like this (fig. 2).

\section{Particular tasks and instructions:}

- Pupils: play and create the rhythm in the axial symmetry.

- Teacher: write down the rhythm, clap the first line and show the symmetric musical response to the students. Then clap the second line with your hands (fig. 1):

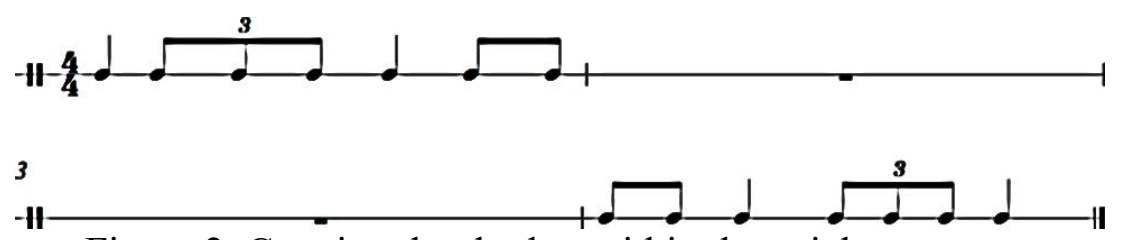

Figure 2. Creating the rhythm within the axial symmetry

- Pupils: use the conscious vocal rhythmisation while particular notes can be sung like rhythmic syllables, for example a quarter note like the syllable "ta-a", two eighth notes like "te-te", four sixteenth notes like "ti-ni ni-ni", and so on.

- Pupils: sing by imitating method the interval according to the axial symmetry while the bar line is the axis (fig. 3): 


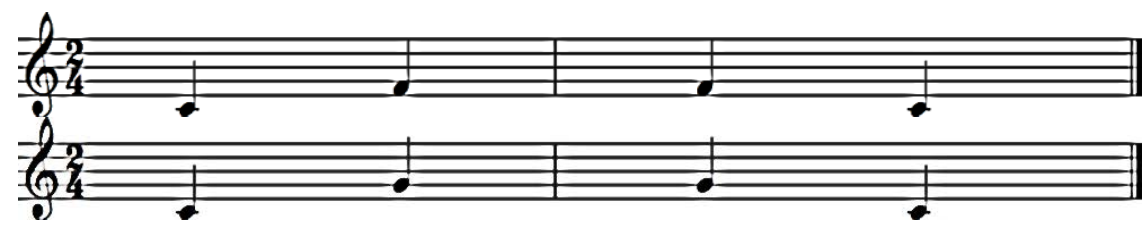

Figure 3. Singing the axial symmetry - imitation

- Variations: Pair work for pupils: one pupil will make up a chord and the other student will sing it backwards (fig. 4). The aim is to improve the intonation, being aware of the pitch of the tone, develop musical memory, concentration and thinking.

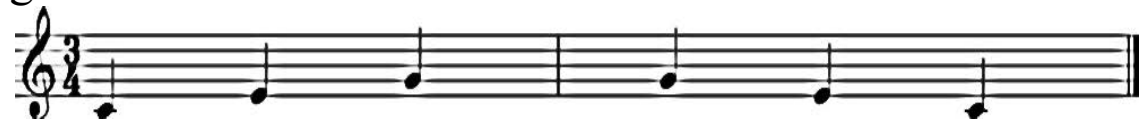

Figure 4. Backward singing

- Pupils: sing the melody according to axial symmetry - the bar line is the axis:

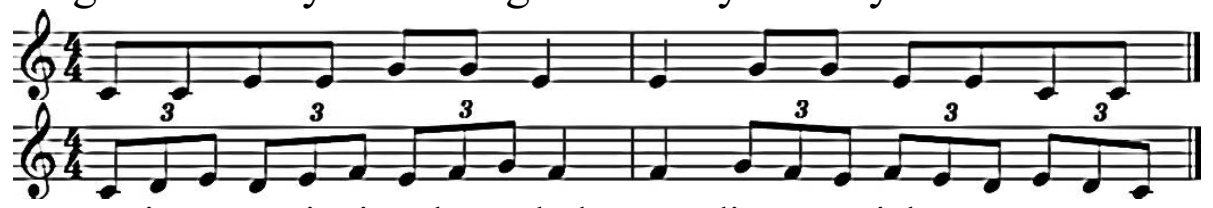

Figure 5. Singing the melody according to axial symmetry

Individual pupil: create your own melody in the tact (and with the help of the teacher it can be written on a blackboard). The other student responses by singing it in the axial symmetry, i.e. backwards (fig. 5).

\section{Organisation of the activity:}

- Teacher or a pupil outlines a flower, a leaf, a face, or whatever object in axial symmetry. Pupils try to draw an exact geometrical figure and transfer it in the axial symmetry.

- Teacher develops rhythmical pattern, performs it to pupils and asks them to sing the "pattern" in the axial symmetry according to the bar line. Pupils create a musical response.

- Teacher invents another rhythm, and students clap it backwards.

- Teacher asks students to work in pairs and create more examples - to improve their music-related memory.

- Intonation symmetry - the teacher writes down the notes and students symmetrically copy them using bar line via axial symmetry.

- The teacher sings the first measure and the students sing their ones. Students continue in pair work - analogically.

- The third musical phase is the sound-tracking of the invented dialogues. One of pupils plays the motive using the bells and another pupil plays it backwards.

- Teacher explains the term crab canon and Renaissance:

Canon is based on the principle of a strict imitation (mirroring) that means one voice copies the melody of the voice which started before.

- The repetition is being conducted with certain belatedness (from 4 to 8 beats).

- Crab canon (curriculum regarding the Renaissance): is being conducted by two players, while one of them plays the main melody from left to right, but the other one plays it backwards, from right to left (fig. 6). 


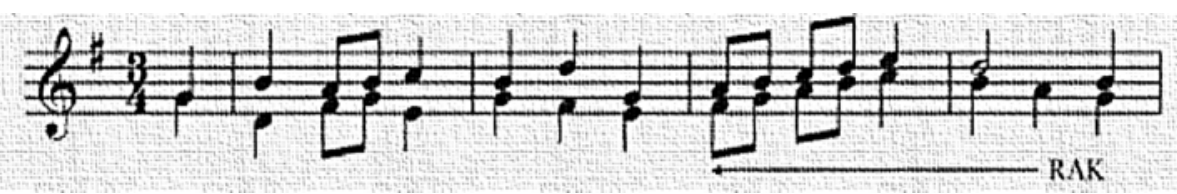

Figure 6. The Crayfish

- The teacher writes a motive on the blackboard and students find only the part which is symmetric to the bar line and delaminate the axis of symmetry (fig. 7). Pupils were supposed to find the part of axial symmetry. It is marked by brown bold line and the notes that do not belong to symmetry are crossed-out (fig. 8).

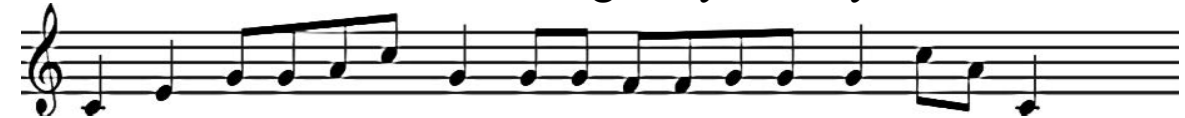

Figure 7. Improvising with a motive and axial symmetry

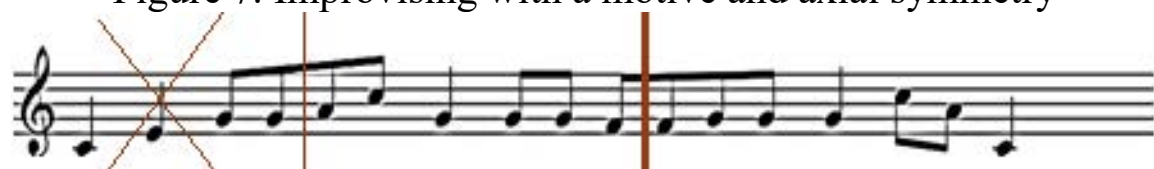

Figure 8 . Defining symmetry by pupils, finding the axis of symmetry and singing axial symmetry

Variations: the following instrumental activities can be used as a modification.

a) Rhythmic symmetric dialogue in pairs using Orff instruments. One pupil creates rhythm while teacher facilitates the process. The rhythm can include syncopation or be all the time the quadruple metre. The other pupil responses in axial symmetry while focusing and reproducing the rhythm backwards.

b) Crab canon in the axial symmetry in pairs. One student makes a short melody playing Orff instruments (orchestral bells) and the other pupil responses using the crab canon in the axial symmetry. They are asked to remember and play the motive backwards.

c) Teacher - student music dialogue: The teacher plays a short motive (can be a part of well-known popular song) and a student reproduces symmetric rhythm, vocally intonates following symmetry.

d) Maths: Two points, A and B, are replaced in the axial symmetry while each of them is being assigned a certain sound. Pupils will draw these points in the axial symmetry according to the axis, and sing them. The same is made with a triangle, square and different geometrical figures. The points can be provided with sound.

\section{Conclusions}

The authoresses described the integration of mathematics and music education which they consider important in increasing pupil motivation and improving class climate. Their own integration of music activities with 11 to 12 year old elementary school pupils proved that they acquired the knowledge about geometrical figures, symmetry and axial symmetry by the development of their conscious rhythmisation and vocal intonation. The class climate with this integration was more positive because pupils created motives and musical responses by playing elementary musical Orff instruments, singing or clapping and by using the technique of crab canon. They acquired the detailed knowledge about what are motives and symmetry in music and in mathematics. 
In music education the emphasis was on precise intonation, development of music-related memory, development of musical thinking, creative musicmaking, inventing simple motives, and the development of instrumental skills. In mathematics emphasis was on the development of imagination, exact drawing, fine motor skills, and of spatial observation.

\section{Acknowledgements}

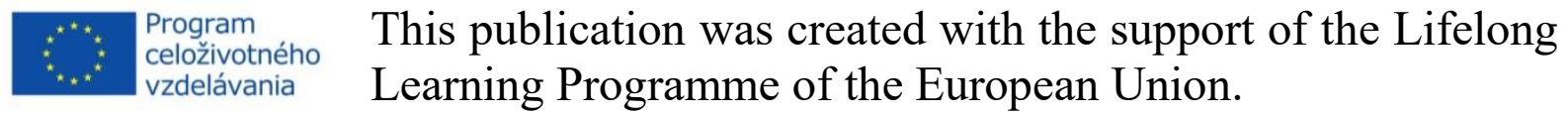

\section{References}

1. Bálint, L'. et al. (2009). Štátny vzdelávací program matematika - vzdelávacia oblast': matematika a práca s informáciami. ISCED 1. Bratislava: ŠPÚ, retrieved 09/04/2015 on:

http://www.statpedu.sk/files/documents/svp/1stzs/isced1/vzdelavacie_oblasti/ma tematika_isced1.pdf

2. Beránēk, J. (2014). Matematické vztahy ve vědě, v reflexi o hudbě a v hudbě (Mathematical relationships in science, in reflection on music and music), Retrieved on November 10, 2014, accessed on: http://www.sciartcz.eu/pdf/Beranek.pdf

2. Hudáková, J. (2015). Matematika $v$ hudbe a hudba v matematike (Mathematics in Music and Music in Mathematics), in "Studia Scientifica Facultatis Paedagogicae Universitas Catholica Ružomberok", Ružomberok: Verbum, vol. XIV, no. 1, pp. 50-57, 216 p

3. Kopčáková, S. (2014). Ozvučenie cesty do matematiky - nové úlohy a možnosti pre hudobnú výchovu (Provision the Path to Mathematics with Music - New Tasks and Possibilities for Music Education), in "Múzy v škole", no 12/2014, Banská Bystrica: UMB

4. Kopčáková, S. (2015). Niekol'ko téz $k$ interdisciplinárnym väzbám hudby a matematiky $v$ súčasnej primárnej edukácii (Several Propositions to Interdisciplinary Bonds between Music and Mathematics in Contemporary Primary Education), in "Studia Scientifica Facultatis Paedagogicae Universitas Catholica Ružomberok", Ružomberok: Verbum, vol. XIV, no 1, pp. 43-49, 216 $\mathrm{p}$

5. Králová, E., Kołodziejski, M. (2015). Music and Class Climate in Lower Secondary Education. Review of Artistic Education, 9-10, 152-163

6. Lifelong Learning Programme Application Form, 2013, "Sounding Ways into Mathematics - EMP- Maths". Retrieved: October 15, 2014, accessed on: http://maths.emportfolio.eu/

7. Prídavková, A., Šimčíková, E. (2015). Rozvoj matematických poznatkov prostredníctvom hudobných aktivít. (Several Propositions to Interdisciplinary Bonds between Music and Mathematics in Contemporary Primary Education). Studia Scientifica Facultatis Paedagogicae Universitas Catholica Ružomberok, XIV(2), 195-199 